\title{
THE IMPLEMENTATION OF COMMUNITY ENGAGEMENT IN PUBLIC SERVICE DELIVERY IN THE UK AND POLICY IMPLICATION TO VIETNAM
}

\author{
Cao Tu Oanh* \\ Faculty of Business Administration \\ VNU University of Economics and Business \\ Received 18 April 2020 \\ Revised 15 May 2020; Accepted 27 May 2020
}

\begin{abstract}
This paper explores how community engagement is implemented by the third sector organisation in public service delivery in the UK. This research applied a case-study approach involving two third sector organisations involved in public service delivery in the UK. The study's findings revealed community engagement as an important aspect in public service delivery that fosters social cohesion and social capital and thus, the implementation of community engagement needs attention to stakeholders' interaction, social network, and capability. The results are discussed in relation to the implications for policy, especially in relation to frameworks that can support public value enhancement.
\end{abstract}

Keywords: Community engagement, Public service delivery, Third sector organisations

Abbreviations: CE(Community engagement), DV (domestic violence), NPM(New Public Management), PPP (Public-private partnership), PSD (Public service delivery), TSOs (Third sector organisations),

\section{Introduction}

The transformation of the welfare state and public service delivery (PSD) in the UK towards marketisation and managerialism resulted from the perceived inefficiency of state-led public services and an increased welfare burden (Osborne and Gaebler, 1992). However, it is also argued that the values created by the market and the state are in conflict, since the goal of the private sector is to create private (economic) value, whilst that of government agencies is to create public (social) value (Moore and Khagram, 2004). This leads to an increased focus on the involvement of the third sector which, it is argued, has the social goals and social legitimacy to understand local needs (Di Domenico et al., 2009a).

\footnotetext{
Tel.: 84-0855776265
}

Email: oanhcao13792@gmail.com; oanhct@vnu.edu.vn
Furthermore, it is important in public service provision to address an effective approach to collaboration and innovative relationships with multiple stakeholders (third sector organisations, community, and the public sector), to deliver what Eriksson (2018) termed 'representative coproduction' and 'value co-creation'. Therefore, community engagement (CE) is seen as an important aspect in PSD that fosters social cohesion (Amin et al.,1999; Davies and Simon, 2012) and social capital (Bovaird et al., 2016), and subsequently social value. CE promotes choices and voices, which lead the service providers and public officials to be more accountable and responsive to the community (Davies and Simon, 2012). In another aspect, CE in PSD is also strengthened through cooperation and co-production with the government and other sectors (Alford, 1998; 
Needham, 2008). Therefore, CE in PSD is more than just being actively involved in decision-making but also being collaborative in producing and delivering services. However, previous research has approached CE based upon the level of power distribution and the role of the community in the relationship with the public sector. Meanwhile, CE is also affected by many contextual factors, such as the institutional environment, citizens' education and awareness of their human rights (Di Domenico et al., 2009a), people's political self-efficacy (Bovaird et al., 2016), and the capability of TSOs.

Over the last four decades, PSD reform has attracted the attention of many researchers and policymakers. Studies on PSD focus mainly on the forms of transformation (Torres and Pina, 2002); the types of partnership and collaboration, including public-private partnerships (PPP) and co-production (Needham, 2008); public service mutuals (Hazenberg and Hall, 2016; Le Grand and Robert, 2018); and community partnership, together with joined-up and entrepreneurial government (Alford and O'Flynn, 2012; Donahue and Zeckhauser, 2011; Osborne and Gaebler, 1992). Previous research also extensively discusses concepts and functions, in addition to the impact of the third sector organizations (TSOs) on the social economy (Young, 2006; Nicholls, 2006), and its involvement in PSD (Di Domenico et al., 2010). There is a lack of an in-depth research on a process of engagement between TSOs as service providers and the community as service users, which can help to identify a better way where public services could deliver a better social impact. This under-researched area is important, as it can provide recommendations for all stakeholders in understanding their community and the implementation of PSD within each context. Therefore, this research explores CE through the observation of process of engagement between community, service providers, and policymakers to reveal the motivation and barriers for interaction and the impacts of that.

In this paper, the research is going to explore the process of CE in PSD in the UK through two case studies. The qualitative coding of data in two case studies revealed important findings on the process of $\mathrm{CE}$ in PSD. Finally, some recommendations to Vietnam are presented.

\section{Literature review}

\subsection{Public services and the third sector}

Humphrey (1998) defines public services as ones that are funded by taxation and mainly include the following areas of public management: central and local government, the health authorities, education, defence, justice/ home affairs, and non-commercial semi-state organisations. He also demonstrates how public services do not need to be delivered by just the government, but that other sectors (private and third) can engage in PSD, albeit still funded from taxation and administrated by central/ local government (Flynn, 2002). Public services are different from private ones in terms of profitability, as they are normally non-profit and non-commercial (Humphrey, 1998). These features distinguish them from the private services provided by the private sector as they have to create profit to distribute to shareholders.

In terms of the relationship with customers, O'Shea (1992) describes that between the customer and state as one of indirect payments, compared to the direct payment relationships between customers and the market. The interaction between customers and the state is not a payment process, but one that is driven through taxation and redistribution. In 
other words, it is a transfer from taxation to redistributed money through public services in order to meet the demands of citizens that otherwise would not be met by the market. This relationship is, however, often not one that is characterised by the community (i.e. the customer) as being overtly engaged in the design and delivery of services. Indeed, it could be argued that in traditional models of PSD the market is one that is supply-side driven, as opposed to one in which suppliers meet demand-led requirements. This is an area where PSD centred on CE can offer additional value (which will be discussed in the next section). Therefore, this paper focuses on public services which are supposed to be delivered by the government but now are transferred to and/ or in collaboration with the community. In this paper, two kinds of public services discussed are public library and services supporting domestic violence victims. The details of cases will be explained in the next section.

With the focus of this paper on the involvement of community in public service delivery, the third sector organisations are the focused public service provider to discuss. TSOs refer to organisations that belong neither to the private sector nor to the public. These organisational forms are normally voluntary/ charitable entities (both trading and non-trading) and social enterprises (including social firms, social businesses, community enterprises, mutual societies, and fair trade companies) (Pearce, 2003). In this paper, the two organisations are a social enterprise led by community (Case 1) and a charitable organisation (Case 2). As public services are different from commercial ones (as demonstrated earlier), the key issue when externalising public services is the selection of service providers, who do not ignore the features of public services as a non-profitable, fair, and equal set of values (Torres and Pina, 2002). In the third system of the economy, social interaction between a variety of actors is the norm in defining the third sector (Moulaert and Ailenei, 2005). Many scholars argue that factors of production (economic capital, human capital) cannot adequately explain contemporary society's undesirable outcomes, such as income inequality and unemployment, and that social and cultural capital, which refers to norms, values and networks, as in Putnam's definition (1993), should also be taken into account. TSOs are said to have a hybrid nature that neutralises the behavioural tensions between the state, the market, and the community (Defourny and Nyssens, 2006). These behavioural tensions are those of market orientation and profit distribution between the state and private sectors; the tension between public and private value that the state and private sectors pursue; and the tension between the formal organisation of the state and informal family, personal and social networks. Therefore, this paper examines the collaboration and engagement between TSOs as service providers and their service users (community) and the authority to deliver better public services.

\subsection{New public government}

The transformation toward more entrepreneurial government with increasing public-private partnerships has been termed New Public Management (NPM). This new theory of public management was first introduced in the UK by Prime Minister Margaret Thatcher during the 1980s and later became the dominant reform strategy across OECD countries (OECD 2004; Pollitt and Bouckeart, 2004). A core feature of NPM is the introduction of entrepreneurial government. The 1980s and early 1990s saw a focus on more customer-based and entrepreneurial government (Osborne and Gaebler, 1992). This transformation is defined and synthesised by Osborne and Gaebler (1992) in Table 1. 
Table 1 - Transformative aspects of entrepreneurial government

\begin{tabular}{|c|c|c|}
\hline Transformation & Traditional government & Transformative government \\
\hline Community owned & Serving people & $\begin{array}{l}\text { Empowering people by placing control } \\
\text { into the community; greater voice of } \\
\text { the private sector; more transparency } \\
\text { in assessing government activities }\end{array}$ \\
\hline Competitive & $\begin{array}{l}\text { Monopoly in delivering public } \\
\text { services }\end{array}$ & Involving other sectors in PSD \\
\hline Result-oriented & Focus on inputs (budget) & Focus on outcomes \\
\hline Mission-driven & Driven by rules and regulations & Driven by mission \\
\hline Customer-driven & Bureaucratic and monopolistic & $\begin{array}{l}\text { Treating clients as customers and } \\
\text { giving them choices }\end{array}$ \\
\hline Anticipatory & Offering solutions to problems & Offering prevention for problems \\
\hline Entrepreneurial & Spending & Earning \\
\hline Decentralised & $\begin{array}{c}\text { Centralised power and } \\
\text { management }\end{array}$ & $\begin{array}{c}\text { Decentralised authority; embracing } \\
\text { participatory management }\end{array}$ \\
\hline Market-oriented & Bureaucratic mechanism & Market mechanism \\
\hline Catalytic & $\begin{array}{l}\text { Rowing (doing everything } \\
\text { directly and on their own) }\end{array}$ & $\begin{array}{l}\text { Steering (catalysing all sectors - } \\
\text { public, private and third - to solve } \\
\text { community problems) }\end{array}$ \\
\hline
\end{tabular}

Source: Summarised from Osborne and Gaebler (1992)

There are three features of this dimension that distinguish a transformative government from a traditional one, namely an interactive relationship with people (empowering, partnering, and involving people in public service provision), an innovative approach to public service provision (diversifying resource mobilisation through decentralisation and market mechanisms, and offering prevention instead of solutions), and outcome-oriented governments which assess efficiency on outcomes, not budget allocation (Osborne and Gaebler, 1992). Therefore, transformative government is more active than the passive traditional government model. The state, by contracting or outsourcing, pays other providers to supply public services to citizens (Le Grand, 2011). Possible alternative external providers could be (other) local government bodies, (other) provincial/ national government bodies, private firms, voluntary agencies, volunteers, clients, and regulators (Alford and O’Flynn, 2012).

\subsection{Public service reform in the UK}

In the UK, under Thatcher's Conservative government, the market-base reform implemented in PSD were through largescale privatisation and decentralisation, which resulted in an overall contraction in the role of the state in PSD (Hula, 1993). Since 1997, the New Labour government applied the "best value" criterion in the performance framework for PSD, and the 'Third Way' policy was first introduced. Many authors have described the Third Way policy as the blending of Thatcher's neoliberalism with new forms of moderate government in order to correct the negative impact of free market policy on the poor (Haugh and Kitson, 2007; Kitson and Wilkinson, 2007). Competition was emphasised as an important feature of the public sector in this period, with the introduction of Compulsory Competitive Tendering (CCT) in some sectors, such as health and local government (Entwistle and 
Martin, 2005). The Third Way policy shows a commitment to providing public services for all, promoting fairness and flexibility through the introduction of choices and voices.

In the UK, the focus on users' needs and collaboration with service providers has been coupled with a focus on using Third sector organisations (TSOs) in public service provision. The Voluntary Sector Compact launched in November 1998 aimed to boost the involvement of the social economy in delivering public services (Osborne and McLaughlin, 2004). A subsequent range of policies/legislation enabling the development of the social economy was introduced, such as the Localism Act 2011 (UK Parliament, 2011), the Public Services (Social Value) Act 2012 (UK Parliament, 2012) and the creation of Public Service Mutuals (spin-outs), which gave powers to local authorities in designing services and encouraged the third sector to participate in PSD (Hazenberg and Hall, 2016). Along with the increasing power of local governments, communities were given more opportunity to investigate and assess how services were being delivered by their government. The relationship between the state and TSOs is structurally interdependent, as TSOs receive significant support from the state, whilst the state can refrain from direct action in certain areas by providing funding. The engagement and interdependent relationship between the state and community in providing social welfare and services in the UK, therefore, is rooted in a long history of liberal government and the development of TSOs in the country.

\subsection{Community engagement in public service delivery}

\subsubsection{Definition of community engagement}

Community engagement (CE) refers to a process that involves people in economic, social, cultural and political actions that directly affect their lives (UNDP, 1993). More specifically, it is a process of collaborating with groups of people who share geographic proximity and interest in addressing issues in relation to their well-being (CDC, 1997). The community can be based on mutual interest (for example, a community of the disabled, or one of young offenders); geographic location (for example, a local or neighbourhood community); or governance and engagement (McCabe et al., 2006). In this paper, the community refers to the residents wholive in the area where public services are provided. They could be public service users (such as library users or domestic violence victims like two cases in this paper) and non-service users but participating in providing the services (such as volunteers, neighbours). The engagement of the community in public activities is demonstrated in a ladder of participation (Arnstein, 1969), as shown in Figure 1.

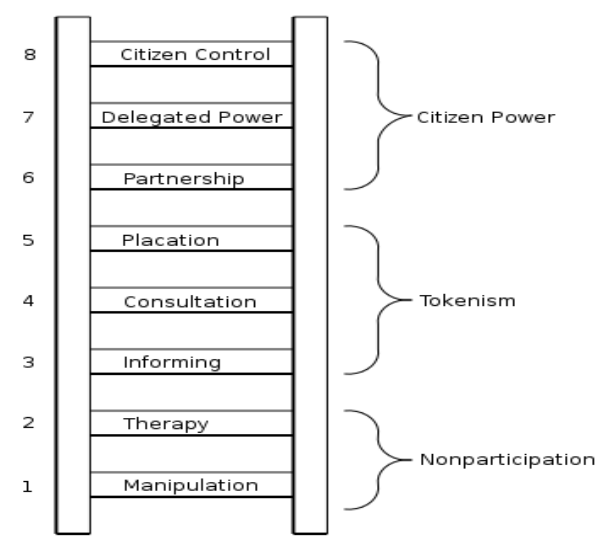

Figure 1 - Ladder of citizen participation (Arnstein, 1969)

The levels of involvement increase from the passive involvement of the community (being informed and consulted) to playing an active role (working directly, partnerships, decision- 
making). In relation to PSD, the engagement of the community is an important aspect of the public service innovation process, as it plays a key role in suggesting new improvements and discovering and identifying issues (Nambisan and Nambisan, 2013; Merickova et al., 2016). Engagement between the community and public organisations in PSD can take three main forms: citizens as co-implementers (the community performs a public service task that used to be performed by public organisations); citizens as co-designers (the community is closely involved in how public services are designed and implemented); and citizens as initiators (the community takes the initiative for public services and the government is invited to join) (Voorberg et al., 2015).

In PSD, CE can also be conducted through intermediaries such as service deliverers, including the private and third sectors. While not all service providers can deliver CE, TSOs who focus on marginalised people can provide social legitimacy and social innovation. This is because they are socially embedded within the community; they are better positioned to understand local issues than the local authority (Di Domenico et al., 2009a). Therefore, policies promoting CE in PSD must support service providers in engaging, empowering and enabling community action/collaboration (Joshi, 2008). This also implies an interactive relationship between policy groups in the policy framework.

\subsubsection{The effect of community engagement}

Community or civic engagement has been regarded as an important element of sustainable development. It is argued that $\mathrm{CE}$ contributes to social capital development (Bovaird et al., 2016). Through participation, people can exchange interests, opinions, capabilities and demands, which lead to a process of mutual understanding and collective action. Through collective co-production, $\mathrm{CE}$ is argued to create more social value-adding outputs to society, through the exchange of individual values in a community, the linkages of the monetised economy, and civic society (Figure 2).

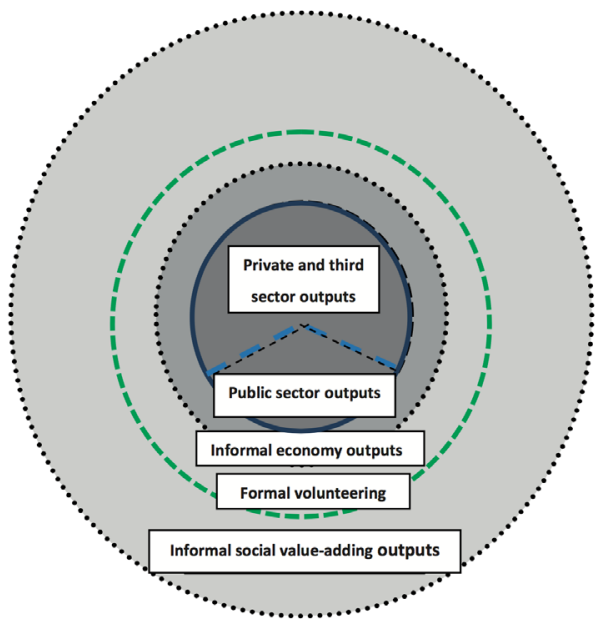

Figure 2 - Economic and social value adding outputs in society (Bovaird et al., 2016)

$\mathrm{CE}$ is also believed to strengthen social cohesion (Amin et al., 1999). Amin et al. (1999) argues that it is not the simple act of participation that leads to social cohesion, but the way participation is conducted, where equality is ensured, transparency and accountability are guaranteed, and intergroup cooperation is required. In PSD, CE must be conducted at multiple levels so as to ensure that accountability, interaction and social intervention are present where needed (as shown in Figure 2). By increasing the choices and voices of $\mathrm{CE}$, public officials and service providers are able to be more accountable to consumers and responsive to their needs. Community participation will, therefore, reduce levels of corruption, increase democracy for citizens, and empower local voices (McGee and Gaventa, 2010). 


\section{Methodology}

\subsection{Overall methodological approach}

The current research use a case-study approach to explore how CE is implemented in PSD in the UK. In each case-study, the qualitative methods used were semi-structured interviews held with managers of both TSOs and the government, and focus groups held with the community (i.e. the service-users of all the cases), in order to assess different perspectives, implementations and outcomes toward CE activities delivered. The findings made reference to the literature in order to make adjustments to the proposed model and ensure that the findings were empirically and theoretically grounded.

A purposive sampling method was adopted. Each case-study was a public service, delivered through engagement and connection with service providers, government and the community, and possibly also alongside professional service providers. The research involved a total of 25 participants with three stakeholders as detailed in Table 2 hereafter.

Table 2: Number of participants

\begin{tabular}{|c|c|c|c|c|}
\hline \multirow{2}{*}{ Number of participants } & \multirow{2}{*}{$\begin{array}{c}\text { Service } \\
\text { providers }\end{array}$} & $\begin{array}{c}|c| \\
\text { Commune/ } \\
\text { village level }\end{array}$ & $\begin{array}{c}\text { Provincial/ } \\
\text { county level }\end{array}$ & \multirow{2}{*}{$\begin{array}{c}\text { Service } \\
\text { users }\end{array}$} \\
\cline { 3 - 4 } & 3 & 2 & 1 & 9 \\
\hline Case 1 & 2 & 0 & 1 & 7 \\
\hline Case 2 & & 2 & 1 & 9 \\
\hline
\end{tabular}

\subsection{Case-studies}

Case 1 - Community libraries in the UK

The two social enterprises in Case 1 are community-led libraries that are entirely run by volunteers and registered as social enterprises. Following the decision of the county council in 2011 that they could no longer afford community library services, public consultations were held to decide the future of library services. In both areas where the two CLs are located, people decided to keep the libraries and a small group of volunteers took charge of running the library services. Therefore, both libraries in their current form were founded in 2012. Both libraries run regular library services with book exchanges, and are restocked from the county council's central library services. In addition, they both have income generation activities from their photocopy machines, and also hold some events through which they raise revenue by charging small fees. However, most of their income is still sourced from grants received from the county council, their respective parish councils, and other donor organisations. Both libraries in Case 1 demonstrate CE through their community events, their local knowledge and networks, as well as their networks of local volunteers. Case 1 shows a model of community empowerment in PSD where community designs and decide the public services they want with the support from the government.

Case 2 - A domestic violence support service provider in the UK

Case 2 is a charitable organisation working in the field of domestic violence support services. It has been running a refuge house for over 35 years with mission of helping women and families suffering from domestic violence. They undertake a range of activities, from raising awareness of domestic violence, running a women's and family's 
refuge house, to training professionals. It is an independent organisation, with funding from a variety of sources, in which the funds provided by the central government and the county council play a significant role. It is important to investigate how the organisation works with the government and how it obtains support from it. Case 2's programmes focus on community demand, and its 'service users' forum that aims to gain feedback from its beneficiaries. This case shows a model of outsourcing public services to TSOs in which the government funded Case 2 to support DV victims. However due to austerity, the fund from the government is reducing and therefore, Case 2 and the government need to find alternative models to deliver better services to the community.

\subsection{Data analysis}

The current research employed 'coding' and the Constant Comparative Method (CCM), as the main tools to analyse the data (Strauss and Corbin, 1990). Data collection stops when a point of saturation is reached and when no new information is emerging (Strauss and Corbin, 1990). This process of coding was followed by the CCM to adjust the categories and concepts of the cases (Lincoln and Guba, 1991). After comparing incidents, the researcher compared them with the property of the categories resulting from the initial comparison. Finally, modification was made to remove irrelevant properties so that the theory could be formed with a smaller set of concepts.

\subsection{Ethical consideration}

As this research is a part of the researcher's $\mathrm{PhD}$ degree, the research plan, proposed methods and ethical protocol were approved by the University of Northampton's Committee where the researcher conducted her $\mathrm{PhD}$ degree before she conducted the fieldwork. Therefore, the researcher had to ensure participants' and organisations' anonymities were protected throughout the study, from data collection, analysis and writing up, to the dissemination of the research. This was done by including a reference number on the consent form and replacing participants' and organisations' names. All the data were stored on the researcher's computer and another backup portable hard drive, with password protected files for both. All the data collected were subject to the Data Protection Act (UK Parliament, 1998) and the General Data Protection Regulation 2018 (GDPR). The researcher also followed the University of Northampton's Code of Practice for Research Ethics to ensure the confidentiality and anonymity of the research.

\section{Discussion and Findings}

The analysis of both cases revealed three major themes, namely: Capability, Engagement, Impacts. The findings from the analysis of the two cases revealed that both had some CE activities delivered through similar forms of engagement. However, the actual level of interaction between the service providers and community, and the impact of the engagement in both cases, were different. Furthermore, it is crucial to discuss the capability of the stakeholders involved in the engagement process.

\subsection{Engagement requires two-way communication and collaboration}

In the theme 'engagement', in both cases, the common $\mathrm{CE}$ forms were 'communication' and 'collaboration'. Regarding 'communication', both cases show the main forms of communication to be 'informing' and 'consultation'. The category 'communication' describes forms of communication between 
service providers, policymakers and the community. Different ways of 'informing' the community emerged, such as publicity, community events, social media, and awareness-raising campaigns. Publicity was disseminated through leaflets, websites and telephone hotlines (promoted by the councils, the police and other organisations). Although these were considered by the organisations as the best means available to them given their resource constraints, both service providers and service users contended that they were not always effective. Although Case 2 made significant efforts to approach the community, the victims reported that they did not know about the organisation until they were referred by other organisations or their social workers.

\section{Case 1:}

"Well, it would be better to have more events here, because if you have an event about something [...] so they come here because of a lecture or a performance or a meeting for a particular group. I think that's one way through, but the other way is leaflets, for example, giving leaflets to real estate agents so they can put them into everybody's hands [...] so it could be a parish council's welcome package to tell them what is going on."

"There are one or two local free magazines, and they tend to put things like local events in free of charge, but sometimes people look at the interesting events in the magazine and it goes in the bin, so it's a tricky angle."

\section{Case 2:}

"We communicate with them in all of those ways. Since I came to the post in 2014, we have made it sound much more accessible I think in terms of the website, Facebook, Twitter, all those sorts of things as well. We even have Instagram posts."

"We've been to the volunteer fair at universities, so a lot of students hear that way.
Wherever we go and talk to raise awareness of the issue of domestic abuse and our service, we then often have a trail of volunteers who come in and say "can I help?"

The information was not always easy to access as most of the people were either disinterested and/or limited in their ability to access the materials and they tended to not have a strong bond with their community. Many of the residents are always on travel and do not communicate often with their neighbours.

\section{Case 1:}

"I suspect there are an awful lot of people that have nothing to do with what happens in the community because it's a dormitory community to a certain extent. People are going out to work early in the morning and come home late at night and are unaware of a lot of activities. So, I think this area is very dependent on some very active, mostly retired, people I would say."

This suggests that the attention to information comes not only from personal interest, but also from social networks through which people share their mutual interests. Indeed, a person's valuation is influenced by that of others (Schumpeter, 1909), and not solely in the economic sphere. Therefore, social interactions and bonds are very important in shaping people's values and perceptions. Without a strong sense of community and local networks, the community in both cases in the UK were potentially unaware of the social problems in the community in which they live. The volunteers in both cases were people who stood up during public consultations and had more local connections, so a better sense of community, which was built up through social interaction (Emerson, 2003). Therefore, these people tended to respond better to the 
information, even though it was given to everybody.

In term of accessibility, the participants reported that one of the barriers to engagement in the services was the lack of available space for the community to held activities and events. In addition, it is very important that accessibility to information is easy, such as leaflets in General Practices (GPs) or women's toilet doors. Furthermore, the online information and social media services provided helped the services become more accessible, thereby promoting CE. Therefore, engagement depends upon the accessibility of the community to the information and services where available.

\section{Case 2:}

"I think there's always room for more. There's a wonderful campaign putting our numbers on the back of women's toilet doors, which is fantastic. Because that's the place you go on your own and you're allowed to go on your own. If you are being controlled and you can see the numbers, and you could choose what you would do with them because you know whether it's safe to write them down or put them on your phone."

'Communication' between the service providers and the local authority was also crucial. The two libraries received significant support from the parish council and county council on advice and training. The county council library staffkept regular communication with the library directors to support them with their needs, and there was a helpline so that the libraries and their volunteers could seek help related to issues they were concerned about. The council also kept track of what was going on in the libraries through annual reports, in which they confirmed whether the library was doing well. Such regular communication is essential for these community-led libraries, as it provides support for problems that they feel they cannot solve. It also demonstrates a good relationship between the service providers and policymakers.

Case 1:

"There is a budget, so you can compare. And we [the county council library] have to make sure we understand their [Case 1] financial issue. If they have anything like problems and they have to close for days and something like that, they send their schedule to us."

"Yes, and building a very good relationship. I like what we have. I [The county council library's officer] always hug them [Case 1's managers] when I see them. They like to tell me everything they are doing, and they also pull in people that have got skills sometimes. They are independent, and we think the main problem would be the managers making sure we have enough people to staff them, also handling difficult volunteers."

However, the communication in both cases in the UK was not only one-way, but was also two-way through 'consultation'. This 'consultation' was conducted between service providers and their users through feedback forms or surveys, and between the local government and their community through public consultations and meetings. The consultation with the service users and the community showed a higher level of engagement, which empowered the community better, as it was given the chance to engage in instrumental-rational social action, which aims to do things in the most efficient way (Weber, 1978). The service users in both cases indicated that they were happy with the engagement meetings, where they could discuss ongoing issues with the service providers. 


\section{Case 1:}

"So it's open when we have the parish council meeting, and this is where we are spending the money when we have the budget [...] So by engaging with people and what they said in the meeting, you get what's important and whether we're prepared to pay the money for it."

"We conduct surveys from time to time, every couple of years. But we find that people are very pleased with the service they received."

"The other thing is we have our volunteer meeting every three weeks, so they actually know what's happening."

Case 2:

"In terms of $\mathrm{CE}$, we've got our own communication team within the police and also our office, the PCC. We've got an organisation that we created called [Organisation name]."

"Yeah, I think it does, I think it's important, but then we have the feedback form that we have to fill in every after a session."

However, when the consultation was taken to the wider (public) level by the local authority, the participants reported that the community was often more neglected and only attracted attention as a result of negative issues.

\section{Case 1:}

"It's a terrible thing that people tend to engage more when it's a negative. If you want people to come to a parish council meeting, you have to have something controversial. If you don't have something controversial, people don't tend to come."

Community consultation was undertaken to capture the range of opinions of the community, not just individual thoughts, and so this is perhaps to some degree inevitable (Spicker, 2006). Although the community's opinions had influence, the organisation or local authority still retained the decision-making power (Bishop and Davis, 2002). This may explain why at a wider public level, the consultation did not always guarantee engagement, as the community was not a homogenous whole, but rather a collection of smaller communities, all from different backgrounds and with different opinions, needs and cultures. In contrast, on a smaller scale, at which they had a closer relationship with and better understanding of the organisation, community consultation was often more effective, as it engaged with a more homogenous group, specifically focused on the aims of the organisation in question. This suggests that it is not the act of consultation that leads to engagement, but that this is mediated by the strength and quality of relationships between service providers and users.

In both cases, especially Case 2, engagement was also implemented through the "collaboration" between community and service providers, and between service providers and local authority. Regarding the collaboration between the community and the service providers, the service provider in Case 1 created many groups and social events to engage and work with the community in their activities. The library also collaborates with local schools or supermarket to held activities or raise fund so that it can spread its impact to the community. The collaboration, in this case, was achieved through a shared vision to maintain a social asset (reading culture) to adapt to the new changed conditions (funding cuts) (Sullivan and Skelcher, 2002). These forms of collaboration were essential to library operation, as by partnering with various stakeholders, the library could take advantage of different resources, get closer to the community, and enrich their service quality. Case 2 engaged their community through the 'involvement' of their users in 
different activities, such as participating in research, creating a service users' forum, involving them in housing tasks, and trying to create more activities to enhance their social interactions. By being involved in groups such as the service users' forum, the community not only had the chance to co-design services, but it was also presented with opportunities to socialise with other people, which is important for social inclusion. Case 2 also tried to engage the service users by involving them in research on projects. These activities were good chances for them to communicate with different stakeholders, giving them a sense of social life and enhancing their self-esteem. They were in effect co-researchers and Case 2 was engaging in co-production.

\section{Case 1:}

"We do have regular activities with the local supermarket [by donated token]. That gives us a little extra, but we are looking at the other ways of making money, that's why we have "the knit and natter" group, which brings in income. We also have the events, you know, a little bit of income. But primarily, we're not there to make money, we are here to be sustainable and continue to offer the services."

"I think there is some linking going on with the primary school. We've got the little ones coming in to use the library more, so the children can understand what's available."

\section{Case 2:}

"You've got like a meeting once a month here, and you are like "what's going on, is there any improvement that can be made, how is everything; there's always opportunity within this, you know?"

"They're also heavily involved in any research if you know one of our programmes is being evaluated by [University name], and they will be involved in a focus group or something like that."
Engagement in such activities can create informal social networks, which are not necessarily based on the neighbourhood, and can promote individualised forms of engagement (Fischer, 1982; Warde et al., 2005). Although community involvement in Case 1 was able to enhance social interactions, Case 1 did not empower the service users to be a part of the decision-making process. One of the directors of Case 1 also contended that the 'friends' scheme' which encourage service users to donate and subscribe to the library service to be a part of the library did not work, because people did not earn the right to vote as they thought they would. This suggests that involvement can only be effective if it can provoke people's voices and power in the decision-making process, which makes it different from mere 'consultation' (Bishop and Davis, 2002). Community involvement in both cases showed that twoway communication can increase trust among stakeholders and empower the community (Grunig and Huang, 2000).

The 'collaboration' between the service providers and the local authority was also a result of community 'involvement'. The county council in Case 2 empowered the community to start the services, involving them in the county council library systems with a range of activities, and collaborating with them to deliver the services. The county council and the Police Crime and Comissioner (PCC) had contracted out the services to certain service providers to provide domestic violence support services. They were aware that they could not do it alone and that these external organisations could do better in terms of CE. Case 2 also worked with other organisations in the field to provide more comprehensive support through supporting agencies that linked organisations together and to the government. These agencies also 
connected the community with the service providers, such as referring volunteers to the organisation. In Case 1, although the libraries were run by the community, the county council still included them in the public library system and provided them with training, book rotation, and held community events through the councils, such as summer reading challenges. Furthermore, the county council contracted out their support services to community development agencies so that the community libraries could seek help regarding volunteers, funds and training from these organisations.

Case 1:

"The council was very keen to keep the library supported and make sure, unlike some other authorities, the community management library is a part of our team so they have the same level of stocks as they had previously. They get new stocks delivered to them, there are not any different to any of these."

"They [the community libraries] could ring us [the county council library] and if they've got any problem with the library management system, a customer's question, stocks gap, probably all of those. I [the county council library's officer] did the training sessions for the library management system and we have webpages for information. And then some of them [the community libraries] need a second training session."

Case 2:

"Absolutely, it needs to be a partnership between all stakeholders, and again, it's what we are trying to have here. We know who our stakeholders are, we work really hard to communicate with them. And I have personally written to the government and have had questions asked in parliament when we haven't had funding in the past, but we need that partnership to extend to include both local government and national government."

\subsection{Capability facilitates the engagement}

The 'capability' theme is an important means of enabling engagement, as it is a primary source of development (Sen, 1988). CE can be achieved through a strategy that develops community knowledge, skills, values and motivations (Littlejohn, 1999). In the two UK cases, the capability of all the stakeholders was expressed through their 'awareness' and 'qualifications'. First, regarding the capability of the community, in both cases it lacked the knowledge and information that was required to have an appropriate understanding of the services. While the community in Case 1 still possessed an idealised vision of an oldfashioned library, the users in Case 2 had little knowledge of how the refuge house operated. The capability of the community was also reported to depend on the background and personal circumstances of the individuals themselves. People who were more active in social activities tended to engage more easily with the services than those who were experiencing social exclusion. Case 1 also revealed that social class also affects people's ability/willingness to engage. People from the middle class and living in a wealthy area (such as the volunteers in Case 1) tended to be more involved in public issues than those who were vulnerable and less educated (such as the victims in Case 2). In Case 2, the community was not aware of their need to engage and/ or how to engage. Furthermore, there were incorrect perceptions of what the services did in the community, which discouraged engagement. For example, before entering the refuge house, the victims had a vague perception of what the place looked like and what they did, which discouraged them from signing up for the services. Therefore, raising awareness is a crucial capability of 
organisations that enhance CE. This also suggests that the contextual conditions of the community can have an impact on their capability to engage.

\section{Case 1:}

"I think it is the general social attitudes toward libraries; that a library isn't an essential place. You might go to a leisure centre, which is more cool, trendy and modern."

\section{Case 2:}

"I think there is a community or people, women. I need to understand what the word refuge means because when you are out there, the perception of a refuge is different. For me, it used to put me off."

Regarding the capability of the service providers, both cases demonstrated their capability to sustainably run the services, even in times of austerity. Both cases are very active in fundraising. In an environment where the voluntary sector has a long history and is well-developed, funding sources in the UK are more diverse. Many characteristics of service providers were identified, such as 'accountability', 'being active', 'being friendly', 'being business minded', 'creativity', and 'dedication'. The service providers in both libraries were reported to be very friendly compared to the time when the council ran the library. The service providers of the current community libraries were much more dedicated and proactive in their activities and events. Both the organisation and community were familiar with the culture of voluntary and fund-raising activities, which enabled them to join together and collaborate in community events to raise funds. Therefore, capability should be accompanied by the availability of opportunities.

Case 1:
"Well, we exercise our brains, and we talk to people. In 2015, we had a series called 'World Apart' and they were all locally sourced speakers. Basically, it is based on the social network that we have with people here; we tried to draw the resources from people who live here."

\section{Case 2:}

"They give a lot of help. If you need an appointment with the council, they will go with you to assist you. They are actually like your back bone."

\subsection{Community engagement facilitates social changes}

Regarding the theme 'impacts', the enhancement of social bonds and social capital in both cases was critical in driving impact. The service users reported that they experienced a sense of community belonging when engaging in the services and social activities that Case 1 and Case 2 had designed for them. Before that, they were socially isolated because of their age or family situation. Users in Case 1 felt that they were part of the town and it brought people together, which strengthened social bonds. People changed their view of the library as a place just to lend books once they had come and used the services there. The events and meetings at the libraries enhanced social interaction, and thus social cohesion. Furthermore, the participants believed that the libraries would provide an important long-term impact by educating the next generation. The service users in Case 2 reported that they felt much more connected to the community when participating in the activities and programmes provided by the organisation. They also had the chance to build more relationships with other people, which helped them to build their confidence and restore their lives. Therefore, social bonds and social capital among the victims were enhanced. 
Case 1:

"I think it is bringing people together, isn't it? Some people go to the library, some people don't. It is different groups in the community that can make a community, isn't it?"

"Well, I think very useful things like the small children when they leave school they first come here, so they grow up knowing we are here. But it is long term, isn't it?"

\section{Case 2:}

"There are opportunities they are trying to provide to you that stop you from sitting in your room with your kids all day. They're like social elements, when you have coffee and chat every Friday."

"Building a link when they're ready with another organisation, being able to come out and volunteer, really helps their confidence and self-esteem, also to build a network for themselves."

More importantly, the service users reported positive changes in themselves after using the services. Users in Case 2 felt much more confident and that they had their self-esteem back. They were given the opportunity to open up about their experience and share it with the community through conferences or involvement in research. The victims were equipped with knowledge and skills that helped them to understand the acts of violence against them and their rights. Changing awareness made the victims much more involved in community activities, such as volunteering or sharing experiences with other victims. This suggests that participation was not just the result of the interaction between the community and service providers, but also of the motivation of the community to engage, which lead to a social change. Indeed, the engagement of a community depends on individual interest, trust, knowledge, and a sense of community belonging (Barkan, 1998).

\section{Case 2:}

"We also give them the opportunity to speak at conferences, often within a sector where we have a conference, we would want input from service users, and it's generally us that provide that."

"There'll be one group of people in the house, they'll leave but then they will come back to volunteer, and the next group will come in."

"I've done freedom, now doing stay free. I find it really useful; it is very helpful; it does help you build up your self-esteem; it's all about you, looking after yourself."

The final category of the theme 'impacts' is 'impact measurement', which reflects the fact that social impact measurement has not been well implemented by both cases. Although both cases did always record any impacts through feedback from their users in order to prove to sponsors that they were delivering good services, they only employed simple frameworks to measure such impacts. The policymakers also admitted they did not undertake much social impact measurement and thought that this would be good to engage with in the future.

Case 1:

"Measuring the impacts, only if we know how to do that. It is hard to measure the impacts, very hard [...] We let them do what they feel they have the capacity to do because they are volunteers. Impacts are so hard to measure. Sometimes they just tell us the differences have been made."

Case 2:

"Going forward, I think it (Social impact measurement) would be a very, very good thing to be able to do. Yes, it has been difficult; we would like to be able to do that. In the past, it hasn't been difficult, going forward we would like to." 


\subsection{The process of community engagement in the UK cases}

From which emerged from the data, Figure 3 outlines this process. Social capital, together with social interaction, social bonds, social networks and mutual understanding, have a great influence on the forms of engagement (which are informing, consultation, involvement and collaboration), and their impacts. Capability, as discussed, is important in transforming social capital into an ability and desire to engage. The social capital created through engagement results in impacts, which eventually create more social bonds and social interactions, and subsequently yet more impact.

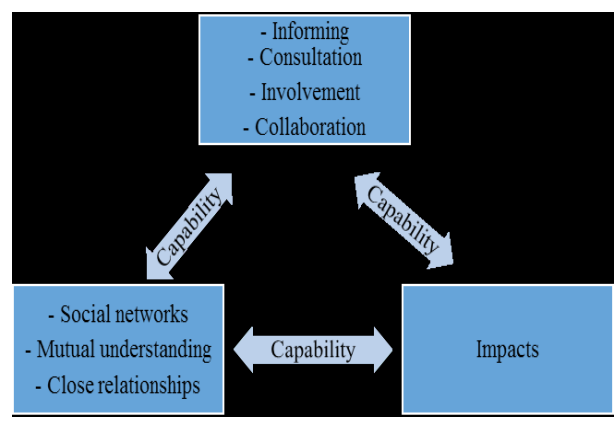

Figure 3 - The process of community engagement in the UK cases

\section{Conclusion and implication to Vietnam}

The paper suggests that regardless of the forms and levels of engagement, $\mathrm{CE}$ should be built on good relationships, mutual understanding and mutual interest. The current research has therefore identified the importance of building social capital in order to improve people's capability to engage. The building of social capital needs to be conducted at many levels and with all stakeholders, between service providers and service users, and between the local authority and the community. This is an area where
Vietnam can learn from the UK, and also other counties in the UK can learn from the example provided through Case 1. Therefore, any strategy in CE needs to be embedded into the building of social capital. This could be done through building good relationships with the service providers and the community.

The analysis also suggests that the capability of the community to engage and that of service provider to encourage the community to engage is an important factor to facilitate the engagement. The long history of third sector development and community empowerment through collaboration and partnership in the UK promotes the collaboration and engagement of the third sector and community in PSD. This could be a lesson learnt for Vietnam in terms of providing more training and support for local authorities and public service officials to equip them with the knowledge and skills to engage in genuine partnership or coproduction with the community. However, the capability of vulnerable groups in the UK is not effective, which suggests that capacity building needs to be targeted at vulnerable or socially disadvantaged groups (Lelkes, 2013).

Finally, the impacts of engagement were revealed to be improvement in social capital and changes to people's self-esteem, subsequently driving CE itself. This finding is important and especially relevant for policymakers in assessing the impact of public services delivered. The focus of social impact, social value creation and community empowerment in the UK is a good reference for Vietnam, such as the Social Value Act 2012 (UK Parliament, 2012) or the Public Contracts Regulations 2015 (UK Parliament, 2015), which empowers commissioners to be innovative and flexible in designing more suitable procurement processes within 
different contexts, partnering with social actors, and inviting social value considerations in all relevant procurement. This improvement in the approach to embedded social value policy implementation is what Vietnam can learn from the UK.

There are a number of research limitations that should be acknowledged. First, the relatively small number of cases. The limited resources did not allow the researcher to travel to as many cases as desired, due to the high travel costs. The limited social networks and resources, as well as the limited time scale, were also barriers to the possibility of approaching more policymakers in the UK, especially national ones, given that the researcher is an international student in the UK. Therefore, the researcher tried to recruit as many participants from all three stakeholders as possible to ensure that each grouphad appropriate representative participants. Thus, this model can be considered to be preliminary one from an exploratory study. By acknowledging the above limitations, the researcher suggests that future research is required. First, employing more cases in both countries would be useful in order to validate and amend the findings of the current research. A larger-scale research project could explore the relationships and engagement between stakeholders in more detail.

\section{References}

Alford, J. (1998). A public management road less travelled: clients as co-producers of public services. Australian Journal of Public Administration. 57(4), 128-137.

Alford, J., \& O'Flynn, J. (2012). Rethinking public service delivery: Managing with external providers. Hampshire: Palgrave Macmillan.

Amin, A., Cameron, A., \& Hudson, R. (1999). Welfare as work? The potential of the UK social economy. Environment and Planning A. 31(11), 2033-2051.

Arnstein, S. R. (1969). A ladder of citizen participation. Journal of the American Institute of Planners. 35(4), 216-224.

Barkan, S. E. (1998). Race, issue engagement, and political participation: Evidence from the 1987 general social survey. Race and Society. 1(1), 63-76.

Bishop, P., \& Davis, G. (2002). Mapping public participation in policy choices. Australian Journal of Public Administration. 61(1), 14-29.

Bovaird, T., Stoker, G., Jones, T., Loeffler, E., \& Roncancio, M. P. (2016). Activating collective coproduction of public services: influencing citizens to participate in complex governance mechanisms in the UK. International Review of Administrative Sciences. 82(1), 47-68.

Center for Disease Control \& Prevention (CDC) (1997). Community engagement: Definitions and organizing concepts from the literature. Available from: http:// www.cdc.gov/phppo/pce/part1.htm. Accessed on 08/08/ 2016.

Davies, A., \& Simon, J. (2012). The value and role of citizen engagement in social innovation, a deliverable of the project: "The theoretical, empirical and policy foundations for building social innovation in Europe" (TEPSIE), European Commission 7th Framework Programme, Brussels: European Commission, DG Research.

Defourny, J. and Nyssens, M. (2006) Defining Social Enterprise. In: M. Nyssens (ed.) Social Enterprise: At the Crossroads of Market, Public Policies and Civil Society. London: Routledge, pp.29-49.

Di Domenico, M., Haugh, H., \& Tracey, P. (2010). Social bricolage: Theorizing social value creation in social enterprises. Entrepreneurship: Theory and Practice. 34(4). 681-703.

Di Domenico, M., Tracey, P., \& Haugh, H. (2009a). Social economy involvement in public service delivery: community engagement and accountability. Regional Studies. 43(7), 981-992.

Donahue, J., \& Zeckhauser, R. (2011). Collaborative Governance: Private Roles for Public Goals in Turbulent Times. Princeton: Princeton University Press.

Emerson, J. (2003). The Blended Value Proposition: Integrating Social and Financial Returns. California Management Review, 45(4), 35-51.

Entwistle, T., \& Martin, S. (2005). From Competition to Collaboration in PSD: A new agenda for research. Public Administration. 83(1), 233-242.

Eriksson, E. M. (2018). Representative co-production: broadening the scope of the public service logic. Public Management Review. 21(2), 291-314.

Fischer, C. S. (1982). To dwell among friends: Personal networks in town and city. Chicago: University of Chicago Press.

Flynn, N. (2002). Public Sector Management. London: Prentice Hall.

Grunig, J. E., \& Huang, Y. H. (2000). From organizational effectiveness to relationship indicators: Antecedents of relationships, public relations strategies and Community Engagement in Australia 233 relationship outcomes. In: Ledingham, J. A. and Bruning, S. D. (eds.) Public relations as relationship management. Mahwah, NJ: Lawrence Erlbaum, 23-53.

Haugh, H., \& Kitson, M. (2007). The Third Way and the third sector: New Labour's economic policy and the social economy. Cambridge Journal of Economics. 31, 973-994. 
Hazenberg, R., \& Hall, K. (2016). Public service mutuals: towards a theoretical understanding of the spin-out process, Policy \& Politics, 44(3), 441-463.

Hula, R. (1993). The state reassessed: the privatization of local politics. In: Goetz, E. and Clarke, S. (eds.) The New Localism. Newbury Park, CA: Sage, pp. 22-45.

Humphreys, P. C. (1998). Improving Public Service Delivery. CPMR Discussion Paper Number 7, IPA: Dublin.

Joshi, A. (2008). Producing social accountability? The impact of service delivery reforms. IDS Bulletin. 38(6), 10-17.

Kitson, M., \& Wilkinson, F. (2007). The economics of New Labour: policy and performance. Cambridge Journal of Economics.31, 805-816.

Le Grand, J. (2011). Quasi-Market versus State Provision of Public Services: Some Ethical Considerations. Public Reason, 3(2), 80-89.

Le Grand, J., \& Roberts, J. (2018). The public service mutual: theories of motivational advantage. Public Administration Review. 78(1), 82-91.

Lelkes, O. (2013). Minimising Misery: A New Strategy for Public Policies Instead of Maximising Happiness? Social Indicators Research. 114(1), 121-137.

Lincoln, Y., \& Guba, E. (1999). Establishing trustworthiness. In Bryman A and Burgess R.G. (eds) Qualitative research. London: Sage Publications, pp. 397-444.

Littlejohn, S. W. (1999). Theories of Human Communication. Belmont, CA: Wadsworth.

McCabe, A. C., Keast, R. L. and Brown, K. A. (2006). Community engagement: towards community as governance. Paper presented to Governments and Communities in Partnership Conference, Melbourne: University of Melbourne, pp. 25-27.

McGee, R., \& Gaventa, J. (2010). Review of Impact and Effectiveness of Transparency and Accountability Initiatives. Paper prepared for the Transparency and Accountability Initiative Workshop, October 2010. Available from: http://www.transparencyinitiative.org/reports/ synthesis-report-impact-andeffectiveness-of-transparency-and-accountabilityinitiatives. Accessed on 11/11/2016.

Merickova, B. M., Svidronova, M. M., \& Nemec, J. (2016). Innovation in Public Service Delivery: Civic Participation in Slovakia. Africa's Public Service Delivery \& Performance Review,4(2), 264-282.

Moore, M., \& Khagram, S. (2004). On creating public value: What business might learn from government about strategic management, Corporate Social Responsibility Initiative Working Paper. 3.

Moulaert, F. and Ailenei, O. (2005) Social Economy, Third Sector and Solidarity Relations: A Conceptual Synthesis from History to Present, Urban Studies. 42(11), pp.2037-2053.

Nambisan, S. \& Nambisan, J. (2013). Engaging Citizens in Co-Creation in Public Services (Lessons Learned and Best Practices). IBM Center for Business of Government.

Needham, C. (2008). Realising the potential of coproduction: negotiating improvements in public services. Social Policy and Society. 7(2), 221-231.
Nicholls, A. (2006). Social entrepreneurship, new models of sustainable social change. Oxford: Oxford University Press.

O'Shea, D. (1992). Customer Care in the Public Sector. Administration, 40(3), pp. 234-247, Dublin: IPA.

OECD (2004). Policy Brief: Public Sector Modernisation: Modernising Public Employment. Paris: OECD.

Osborne, D., \& Gaebler, T. (1992). Reinventing Government: How the Entrepreneurial Spirit is Transforming the Public Sector, Reading: AddisonWesley Publishing Company. Inc.

Osborne, S. P., \& McLaughlin, K. (2004). The crosscutting review of the voluntary sector: where next for local government-voluntary sector relationships? Regional Studies. 38(5), 571-580.

Pearce, J. (2003) Social Enterprise in Anytown, ESRC, Calouste, Gulkenian Foundation: London.

Pearce, J. (2003). Social Enterprise in Anytown, ESRC, Calouste, Gulkenian Foundation: London. Available online at: http://www.esrc.ac.uk/ESRCInfoCentre/ Images/diagram\%20for\%20se_tcm6-28096.pdf. Accessed on 19/09/2015.

Pollitt, C., \& Bouckaert, G. (2004). Public Management Reform: A Comparative Analysis. Oxford: Oxford University Press.

Putnam, R. D. (1993) Making Democracy Work: Civic Traditions in Modern Italy. Princeton: Princeton University Press.

Schumpeter, J. A. (1909). On the Concept of Social Value. The Quarterly Journal of Economics. 23(2), $213-232$.

Sen, A. (1988). The standard of living: lecture I, concepts and critiques. In: Sen, A. and Hawthorn, G. (1988) The standard of living. Cambridge: Cambridge University Press.

Spicker, P. (2006). Policy analysis for practice: Applying social policy. Bristol, UK: Policy Press.

Strauss, A., \& Corbin, J. M. (1990). Basics of qualitative research: Grounded theory procedures and techniques. Thousand Oaks, CA: Sage Publications, Inc.

Sullivan, H., \& Skelcher, C. (2002). Working across boundaries: Collaboration in public services. New York: Palgrave Macmillan.

Torres, L. \& Pina, V. (2002) Delivering Public Services Mechanisms and Consequences: Changes in Public Service Delivery in the EU Countries. Public Money \& Management, 22(4), pp.41-48

Torres, L., \& Pina, V. (2002). Delivering Public Services - Mechanisms and Consequences: Changes in Public Service Delivery in the EU Countries. Public Money \& Management, 22(4), 41-48.

UK Parliament (2011). The Localism Act 2011. Available from http://www.legislation.gov.uk/ukpga/2011/20/ contents/enacted. Accessed on 13/06/2016.

UK Parliament (2012). Public Services (Social Value) Act 2012. Available from http://www.legislation.gov. uk/ukpga/2012/3/enacted. Accessed on 13/06/2016. 
UK Parliament (2015). The Public Contracts Regulations 2015. Available from http://www. legislation.gov.uk/uksi/2015/102/contents/made. Accessed on 24/07/2016

UNDP (1993). Human Development Report 1993. New York: Oxford University Press.

Voorberg, W. H., Bekkers, V. J., \& Tummers, L. G. (2015). A systematic review of co-creation and co-production: Embarking on the social innovation journey. Public Management Review, 17(9), 1333-1357.
Warde, A., Tampubolon, G., \& Savage, M. (2005). Recreation, informal social networks and social capital. Journal of Leisure Research. 37(4), 402-425.

Weber, M. (1978). Economy and Society. Berkley, CA: University of California Press.

Young, R. (2006). For What It Is Worth: Social Value and the Future of Social Entrepreneurship. In: Nicholls, A. (ed.) Social Entrepreneurship: New Models of Sustainable Social Change. Oxford: Oxford University Press, pp.56-74.

\title{
GẮN KẾT CộNG ĐỒNG TRONG PHÂN PHỐI DİCH VU CÔNG Ở VƯO'NG QUỐC ANH VÀ HÀM Ý CHÍNH SÁCH CHO VIẸTT NAM
}

\author{
Cao Tú Oanh \\ Viện Quản trị Kinh doanh \\ Truoòng Đại học Kinh tế, Đại học Quốc gia Hà Nội
}

Tóm tắt: Bài báo phân tích việc thực hiện gắn kết cộng đồng trong phân phối dịch vụ công được thực hiện bởi các tổ chức thuộc khu vực thứ ba (The Third sector organisations) tại Vương quốc Anh. Nghiên cứu sử dụng phương pháp nghiên cứu trường hợp điển hình tại hai tổ chức thuộc khu vực thứ ba tham gia phân phối dịch vụ công tại Vương quốc Anh. Bài báo chỉ ra rằng gắn kết cộng đồng là một yếu tố quan trọng trong phân phối dịch vụ công, giúp thúc đẩy sự phát triển của vốn xã hội và gắn kết xã hội. Do đó, việc gắn kết cộng đồng trong phân phối dịch vụ công cần được quan tâm tới thúc đẩy sự tương tác và năng lực của cộng đồng, người cung cấp dịch vụ, và chính quyền. Các kết quả của bài báo được thảo luận trong mối liên hệ với các hàm ý chính sách, đặc biệt là các chính sách thúc đẩy việc tạo ra giá trị xã hội.

Tù khóa: Gắn kết cộng đồng, Phân phối dịch vụ công, Tổ chức thuộc khu vực thứ ba 